\title{
A comparison of the food intake of elderly women estimated by the individual inventory and the National Food Survey methods
}

\author{
By J. V. G. A. DURNIN AND ELAINE C. BLAKE \\ Institute of Physiology, University of Glasgow \\ (Received 20 October $\mathrm{196}$ I-Revised I $_{5}$ Fanuary I962)
}

In a previous paper (Durnin, Blake, Brockway \& Drury, I96I) we reported the energy expenditure and the intake of calories and of nutrients by seventeen elderly women, aged between 60 and 69 years, living alone. Their mean intake and expenditure of calories were about $1900 \mathrm{kcal} /$ day. Intake of nutrients was assessed by the individual-inventory method, in which the separate items of food are weighed immediately before eating, and any plate wastage remaining after the meal is deducted; the mean result obtained by this method for these elderly women agreed within $5 \%$ with their mean energy expenditure. A value of $1900 \mathrm{kcal} /$ day also approximates closely to the supposed physiological requirements of women of this age and bodyweight $(6 \mathrm{r} \mathrm{kg}$ ), and to several official recommendations for calorie allowances. However, I $900 \mathrm{kcal} /$ day is very much lower than results obtained in the National Food Survey (NFS) in Britain (Ministry of Agriculture, Fisheries and Food: National Food Survey Committee, 1960), indicating that the food purchases of elderly women, living alone and aged 60-69 years, averaged about $2900 \mathrm{kcal} /$ day. Even if losses in preparation and plate wastage are allowed for, this seems a surprisingly large amount, as has been noted by Baines \& Hollingsworth (1955) when considering previous similar findings of the NFS.

The subjects in the study mentioned (Durnin et al. 196r) recorded their food purchases by the NFS method, as well as having their food intake and energy expenditure measured, in order to allow a direct comparison between the methods. Other subjects, not dealt with in the previous paper, recorded only their food purchases so that any possible bias, caused by the several sets of concurrent recordings, might be elicited. The present paper reports and discusses the results obtained on both groups of women.

\section{METHODS}

All the women lived in Paisley, a large town near Glasgow. The investigation was undertaken in two stages, ten women being studied in March and another thirteen in November. With the first ten subjects measurements of total food intake and energy expenditure were made, and food purchases were recorded, during a period of I week. Since it is possible that these procedures might have influenced eating habits or food purchases (although attempts were continually made to avoid such a disturbance and little evidence of it was apparent), a different method was used in the second stage. 
The thirteen subjects in the November survey were divided into two groups, seven women being assessed as before for energy output, food intake and food purchases, whereas the remaining six only noted down the food entering the house during the week of study. Thus seventeen women provided combined measurements of energy expenditure, food intake and food purchases and six women provided data only on food purchases. There was no significant difference between the results obtained in the March and November investigations, so they have been combined.

Selection of subjects. A random sample of women aged $60-69$ and living alone in separate households was drawn, by blocks, from the registers of patients kept by the National Health Service Local Executive Council in Paisley (see Durnin et al. (196r) for details)

Physical characteristics of subjects. The mean age of the twenty-three women was 65.5 years, the mean height was $153^{.} \mathrm{I} \mathrm{cm}$ (range $\mathrm{I} 34^{-162.5}$ ) and the mean weight was $60^{\circ} 5 \mathrm{~kg}$ (range $41^{\circ} \cdot 4^{-80} \cdot 0$ ). Most of them were physically fit and quite active, although one suffered from mild diabetes, one had a 'myocarditis' and two or three had rheumatic disorders. There were no obvious signs of scurvy in any subject.

The living conditions were similar to those described previously (Durnin et al. I96I).

Measurement of food intake. Food intake was measured by the individual-inventory method previously described (Durnin et al. 196r).

Estimation of food purchases by the NFS method. Each subject kept a record of food purchases, including weight and cost, any food acquired 'free' from gardens, allotments or gifts, any food given away or meals given to visitors, and any meals taken outside the home. In addition, a record including weight was obtained, by the investigators, of larder stocks at the beginning and end of the survey. This information was collected in such a way that it could be compared with similar data assembled in the NFS.

The method followed in the NFS of calculating the nutrient value of the food available for consumption was changed to years ago. Before $195 \mathrm{I}$, changes in larder stocks were allowed for. Since then, no adjustments for changes in larder stocks (which are not now measured) have been made in the final calculations of food consumption by households, since it was thought that on average, for large groups, additions to and withdrawals from larder stocks would cancel each other out. Neither method of calculation takes account of boiled sweets or chocolate, soft or other drinks, or meals eaten away from home. The present paper, however, tabulates the results as computed by both the pre-195 I method and the current method, and allowances are made for meals given to visitors or eaten outside the home.

The nutrient value of the food was calculated from tables adapted from those of the Medical Research Council: Accessory Food Factors Committee (1945), which are at present used for assessing NFS data. 


\section{RESULTS}

The values obtained for calories, protein, fat, carbohydrate, calcium and iron for the six women providing data on food purchases only are shown in Table I. Values in the separate columns have been calculated in the following way. Column A is based on the current NFS procedure, i.e. changes in larder stocks were not considered; it therefore estimates the nutritive value of all foods purchased during the week of the survey, together with gifts of food received and special withdrawals from larder stocks of home-produced foods stored in bulk, such as preserves. Column B ('per head (adjusted)') deducts values for meals given to visitors and adds values for meals eaten outside the house. The values in column C ('per head') are equivalent to the data obtained by the NFS assessments as they were made before 1951 , i.e. they include values for foods purchased, food obtained from gardens or allotments and gifts of food, and for the difference in the larder stocks during the survey. Values for gifts to other households are deducted. In column D ('per head (adjusted)'), the value for food given to visitors is deducted and food eaten outside the home is added.

Table I. Mean daily mutrient content of food available for consumption, as estimated for six elderly women who undertook the National Food Survey procedure only

\begin{tabular}{|c|c|c|c|c|}
\hline & \multicolumn{2}{|c|}{ NFS method, current } & \multicolumn{2}{|c|}{ NFS method before I95I } \\
\hline & $\begin{array}{c}A^{*} \\
\text { per head }\end{array}$ & $\begin{array}{c}\mathrm{B}^{*} \\
\text { per head } \\
\text { (adjusted) } \dagger\end{array}$ & $\begin{array}{c}C^{*} \\
\text { per head }\end{array}$ & $\begin{array}{c}\mathrm{D}^{*} \\
\text { per head } \\
\text { (adjusted) } \dagger\end{array}$ \\
\hline Energy value (kcal) & I 678 & 1737 & 1908 & 1988 \\
\hline Protein $(\mathrm{g})$ & $51 \cdot 0$ & $53 \cdot 4$ & $55 \cdot 7$ & $5^{8 \cdot 6}$ \\
\hline Fat $(\mathrm{g})$ & $78 \cdot 7$ & $82 \cdot 3$ & $77 \cdot 7$ & $80 \cdot 9$ \\
\hline Carbohydrate (g) & $190 \cdot 2$ & $194^{\circ} 0$ & $245^{*} 4$ & $255 \cdot 3$ \\
\hline Calcium (mg) & 625 & 658 & 735 & 772 \\
\hline Iron (mg) & $9 \cdot 5$ & $10 \cdot 0$ & I I 3 & II 9 \\
\hline
\end{tabular}

The mean weight and build of the six women who provided the data for Table I were almost identical to those of the larger group studied. This larger group of seventeen women provided information on food intake, energy expenditure and NFS records. The apparent consumption of food by each of the two groups was very similar, the values for the women providing only NFS records being somewhat smaller. The data supplied by all twenty-three women have therefore been combined, and Table 2 shows the values for the intakes of nutrients calculated by the different methods. The values in columns $\mathrm{A}, \mathrm{B}, \mathrm{C}$ and $\mathrm{D}$ were estimated as described above. Column $\mathrm{E}$ gives the values obtained by the individual-inventory method. When the amount of the edible wastage (column $\mathrm{F}$ ) is deducted from the values in columns $\mathrm{A}-\mathrm{D}$, the agreement between the different methods of assessment is seen to be very satisfactory (column $B$ value $=\mathrm{r} 86_{5} \mathrm{kcal} ;$ column $\mathrm{C}$ value $=\mathrm{r} 865 \mathrm{kcal} ;$ column $\mathrm{D}$ value $=\mathrm{I} 96 \mathrm{r} \mathrm{kcal}$; column E value $=1894 \mathrm{kcal}$ ), with the exception of the current NFS method (column 
A value $=1769 \mathrm{kcal}$ ) which might seem to give too low a value. The mean cost of the week's food is also given in Table 2, together with the range.

If breakfast, dinner, tea and supper are counted as meals, about $15 \%$ of the total meals eaten during the week were taken away from home. This is a socially interesting fact showing that the subjects were by no means lonely elderly ladies. The nutritional significance, however, is small, since the meals eaten away from home accounted for only about $2 \%$ of the total calorie intake. Many of the women also had occasional visitors for meals, but again the consumption of the visitors represents only a very small amount of food, about $1-2 \%$ of the total intake.

The quantitative difference in the larder stocks measured at the beginning and end of the I week survey was equivalent to about $550 \mathrm{kcal} / \mathrm{head}$, i.e. a mean daily value for each woman of about $80 \mathrm{kcal}$.

Table 2. Mean daily nutrient content of diets of elderly women, as assessed by different methods

\begin{tabular}{|c|c|c|c|c|c|c|}
\hline & \multicolumn{2}{|c|}{ NFS method, current } & \multicolumn{2}{|c|}{ NFS method before I95 I } & \multirow{2}{*}{$\begin{array}{l}\text { Individual- } \\
\text { inventory } \\
\text { method } \\
\mathrm{E}^{*} \\
\text { per head } \\
\text { (I7) }\end{array}$} & \multirow[b]{2}{*}{$\begin{array}{c}\text { Edible } \\
\text { wastage } \\
\text { F* } \\
\text { per head } \\
(17)\end{array}$} \\
\hline & $\begin{array}{c}A^{*} \\
\text { per head } \\
(23)\end{array}$ & $\begin{array}{c}\mathbf{B}^{*} \\
\text { per head } \\
\text { (adjusted) } \dagger \\
(23)\end{array}$ & $\begin{array}{c}C^{*} \\
\text { per head } \\
(23)\end{array}$ & $\begin{array}{c}\mathrm{D}^{*} \\
\text { per head } \\
\text { (adjusted) } \dagger \\
(23)\end{array}$ & & \\
\hline $\begin{array}{l}\text { Energy value (kcal) } \\
\text { Protein (g) }\end{array}$ & 1834 & $\begin{array}{l}193^{\circ} \\
60.7\end{array}$ & $\begin{array}{l}193^{\circ} \\
57 \cdot 1\end{array}$ & $\begin{array}{c}2026 \\
60 \cdot 8\end{array}$ & $\begin{array}{r}1894 \\
62.4\end{array}$ & $\begin{array}{l}65 \\
2 \cdot 6\end{array}$ \\
\hline $\begin{array}{l}\text { Protein }(\mathrm{g}) \\
\text { Fat }(\mathrm{g})\end{array}$ & $\begin{array}{l}57.5 \\
83.0\end{array}$ & $\begin{array}{l}60 \cdot 7 \\
88 \cdot 0\end{array}$ & $\begin{array}{l}57 \cdot 1 \\
82 \cdot 6\end{array}$ & $\begin{array}{l}60 \cdot 8 \\
87 \cdot 0\end{array}$ & $\begin{array}{l}62.4 \\
85.7\end{array}$ & $\begin{array}{l}2 \cdot 6 \\
3.5\end{array}$ \\
\hline Carbohydrate $(\mathrm{g})$ & $216 \cdot 7$ & $225 \cdot 3$ & $238 \cdot 8$ & $249 \cdot 7$ & $232 \cdot 1$ & $6 \cdot 0$ \\
\hline Calcium (mg) & 759 & 810 & 793 & 845 & 845 & $20 \cdot 4$ \\
\hline Iron (mg) & II I I & II.O & II. 3 & II 99 & 10.7 & 0.6 \\
\hline
\end{tabular}

Figures in parentheses are the numbers of subjects.

Mean weekly cost of food $£, 1.5 s$. I $d$. (range from I 2s. $2 \frac{1}{2} d$. to $£$ I. I $9 s .5 \frac{1}{2} d$.) (includes gifts of approximate value $6 d$. per week per head).

* See p. 263.

$\uparrow$ Adjusted for meals out and for visitors' meals.

\section{DISCUSSION}

Estimates (by the current NFS method) of the food consumption of elderly women living alone have given, over a number of years, consistently high figures. Food equivalent to $2900 \mathrm{kcal} /$ day has apparently been obtained for consumption by women aged 60 and 69 years living alone. When the usual allowance (about 10\%) has been made for wastage, this still leaves about $2600 \mathrm{kcal} /$ day as the apparent intake of these women, which is far above the mean physiological requirement of the group (possibly about $1900 \mathrm{kcal} / \mathrm{day}$ ). Measurements of energy expenditure, and of food intake by the individual-inventory method, of a group of seventeen women, aged 60-69 years and living alone, showed their intake and output of energy to be about $1900 \mathrm{kcal} /$ day (Durnin et al. 1961). The calculation of the food intake of these seventeen women, by methods similar to the current NFS method and to the NFS method before 195 I, gives results equivalent to about $1900 \mathrm{kcal} /$ day. Similar results were obtained when these NFS methods were applied to the records of the six elderly women who provided 
data on food purchases only. Wastage of edible food was almost negligible. Changes in larder stocks were of small importance. The random selection of the group, and the fact that the differences between these results and those of the NFS are so large, makes it most unlikely that the differences have occurred by chance.

Our experiment was carried out by a team of dietitians and the results obtained appear reasonable and acceptable from the physiological standpoint. It is therefore improbable that they are grossly unrepresentative of the normal intake of the elderly women studied, and that the usual routine of the women was upset in such a way that a marked underestimate was obtained of their food consumption. Moreover, in this and in our previously reported surveys, the independent measure of total energy expenditure usually differed little, in the group mean, from that of the intake of calories.

\section{SUMMARY}

I. Twenty-three elderly women had their food intake assessed by methods similar to those of the current National Food Survey in Britain and also to those of the Survey as it was conducted before $195 \mathrm{I}$.

2. The results have been compared with results obtained by the individual-inventory method. The NFS (pre-I95 I) method and the weighing method gave similar values for the calorie intake, about $1900 \mathrm{kcal} / \mathrm{day}$. Calculation by the current NFS method gave slightly lower values.

3. These values are, however, much lower than those obtained in the current NFS in Britain. No immediate explanation of the difference emerges from this study.

This work was carried out during the tenure by J. V. G. A.D. of a research grant from the Scottish Hospital Endowments Research Trust. Part of the funds were given by the Department of Health for Scotland and part by the Medical Research Council.

We are grateful to Miss Dorothy Hollingsworth of the Ministry of Agriculture, Fisheries and Food and to Dr W. T. C. Berry of the Ministry of Health, who instigated part of the study. We are also indebted to Dr R. A. Robb of the Department of Statistics, University of Glasgow for statistical assistance, to the officials of the National Health Service Local Executive Council in Paisley for assistance in selecting the subjects and to Sir Kenneth Cowan, Department of Health for Scotland, for advice.

\section{REFERENCES}

Baines, A. H. J. \& Hollingsworth, D. F. (1955). Proc. Nutr. Soc. 14, 77.

Durnin, J. V. G. A., Blake, E. C., Brockway, J. M. \& Drury, E. A. (1961). Brit. F. Nutr. I5, 499.

Medical Research Council: Accessory Food Factors Committee (1945). M.R.C. (War) Memor. no, I4.

Ministry of Agriculture, Fisheries and Food: National Food Survey Committee (1960). Domestic Food Consumption and Expenditure: 1958. London: H.M. Stationery Office. 